\title{
Koreksi Bias Data Hujan Luaran GCM ECHAM5 Untuk Prediksi Curah Hujan Bulanan dan Musiman Pulau Lombok
}

\author{
Bias Correction for GCM ECHAM5 Model Rainfall Data Output in \\ Estimating Monthly and Seasonally Rainfall for Lombok Island
}

\author{
Humairo Saidah*, Agustono Setiawan, Lilik Hanifah, \\ Eko Pradjoko, Agus Suroso \\ Jurusan Teknik Sipil Fakultas Teknik, Universitas Mataram \\ *corresponding author, email: $\underline{\text { h.saidah@unram.ac.id }}$
}

Manuscript received: 10-12-2021. Accepted: 21-12-2021

\begin{abstract}
ABSTRAK
Penelitian ini bertujuan untuk mengkoreksi data luaran model GCM ECHAM5 untuk estimasi curah hujan bulanan di Pulau Lombok. Data yang digunakan pada penelitian ini adalah data hujan bulanan luaran ECHAM5 dan data hujan hasil pengukuran automatic rainfall recorder (ARR) tahun 2000-2018 untuk stasiun Gunung Sari. Koreksi bias dilakukan dengan metode rasio rata-rata dan model proyeksi data hujan disusun menggunakan metode regresi sederhana. Model regresi terbaik dihasilkan dari pendekatan baik model linier maupun non linier. Evaluasi dan validasi ketelitian model menggunakan nilai koefisien korelasi Pearson (r), nilai Root Mean Square Error (RMSE) dan Nash-Sutcliffe Efficiency (NSE). Hasil yang diperoleh adalah data hujan harian maupun bulanan luaran model ECHAM5 tidak dapat langsung digunakan untuk menggantikan data hujan pengukuran karena ketelitiannya yang rendah. Teknik downscaling yang dilakukan pada data hujan harian dan bulanan dengan metode rasio rata-rata juga belum menunjukkan kinerja yang memuaskan meskipun diperoleh peningkatan angka efisiensi dan penurunan angka simpangan. Namun data model ECHAM5 dapat digunakan untuk mendapatkan angka proyeksi curah hujan bulanan dan musiman dengan angka korelasi yang baik dan memuaskan.
\end{abstract}

Kata kunci: metode rasio rata-rata; model iklim global; ECHAM5; hujan bulanan

\section{ABSTRACT}

This study aims to evaluate the ability of the ECHAM5 GCM model output data in estimating monthly rainfall on the island of Lombok. The data used in this study are ECHAM5 monthly rainfall data and automatic rainfall recorder (ARR) measurement rain data for 2000-2018 obtained from ARR Gunung Sari. Correction of bias is conducted by using the mean ratio method and the regression method. The method that produces the best approach is then used to obtain rain data projections and a simple regression method. Evaluation and validation used the Pearson correlation coefficient (r), Root Mean Square Error (RMSE) and Nash-Sutcliffe Efficiency (NSE) values. The results obtained are that the 
daily and monthly rainfall data from the ECHAM5 model cannot be directly used to replace the rain measurement data because of its very low accuracy. The downscaling technique performed on daily and monthly rainfall data using the average ratio method does not show satisfactory performance where the efficiency figures produced are still low even gave a slight increasing number. However, the ECHAM5 model data can be used to obtain rainfall projections on a monthly and seasonal scale with a good and satisfactory correlation.

Key words: mean ratio method; global climate model; ECHAM5; monthly rainfall.

\section{PENDAHULUAN}

Data hujan merupakan salah satu data utama yang digunakan dalam berbagai studi untuk keperluan pengelolaan dan perancangan infrastruktur sumberdaya air. Data hujan digunakan untuk analisis ketersediaan air pada suatu wilayah (Bunganaen et al., 2020; Hutama et al., 2021; Osly et al., 2019) hingga untuk memprediksi besaran dan peluang dari kejadian banjir (Abdulhalim et al., 2018; Saidah et al., 2020; Sutanto, 2020; Talumepa et al., 2017) dan kekeringan(Chaniago, 2021; Novita et al., 2021; Saidah et al., 2017; Utami et al., 2021). Berbagai analisis hidrologi sangat bergantung pada ketersediaan data hujan sebagai material input selain data iklim lainnya, seperti analisis kebutuhan air irigasi (Aprilestari et al., 2021; Negara et al., 2020), debit andalan (Azhar and Gunawan, 2021; Sudinda, 2020), debit banjir rencana (Nggarang et al., 2020; Pariartha et al., 2021), termasuk juga analisis karakteristik kekeringan. Untuk keperluan tersebut maka dilakukan pencatatan curah hujan menggunakan alat ukur hujan yang diletakkan pada lokasi tertentu mengikuti kemerataan sebaran yang disyaratkan.

Pencatatan data hujan pada suatu daerah umumnya direkam menggunakan rain gauge yang diletakkan mengikuti pola sebaran tertentu. Curah hujan yang diperoleh berupa hujan titik (point rainfall) yang hanya mewakili hujan pada lokasi stasiun hujan tersebut berada. Sedangkan untuk menggambarkan curah hujan wilayah, masih diperlukan data hujan dari stasiun yang lain yang ada di sekitarnya. World Meteorological Organization (WMO) telah merekomendasikan bahwa data dari satu stasiun pengamat cuaca dan iklim hanya dapat dipergunakan untuk mewakili wilayah seluas $100 \mathrm{~km} 2-1000 \mathrm{~km}^{2}$ (World Meteorological Organization, 2010).

Namun pencatatan data hujan yang lengkap dan panjang baik periode pencatatan maupun keterwakilan lokasi terkadang sulit untuk didapatkan (Perdana et al., 2015). Hal ini menghambat berbagai upaya penelitian maupun kegiatan analisis dalam bidang sumber daya air. Pemanfaatan data hasil penginderaan jauh maupun pendekatan melalui model iklim global/Global Circulation Model (GCM) dapat menjadi alternatif sumber data, utamanya pada daerah yang tidak memiliki alat ukur hujan. Namun data model global tersebut pada umumnya tidak dapat langsung digunakan, melainkan perlu diubah terlebih dahulu ke dalam skala lokal serta dilakukan penyesuaian.

Penyesuaian data GCM menjadi informasi yang berskala lokal dilakukan dengan statistical downscaling, yaitu pendekatan model statistika yang melihat hubungan data yang berskala besar dengan data yang berskala lokal (Araya-Osses et al., 2020; Asyeifa, 2017; Sachindra et al., 2018). Dalam hal ini pola hubungan antara kedua variabel dapat bersifat linier 
maupun non linier dan dilakukan pendekatan hingga diperoleh hubungan fungsional yang baik antara data model dan data pengukuran (Maraun et al., 2019; Sachindra et al., 2018).

\section{BAHAN DAN METODE}

Bahan yang digunakan dalam penelitian ini adalah set data hujan harian luaran model iklim ECHAM5 dan data hujan pengukuran dari stasiun hujan ARR yang ada di pulau Lombok. Data hasil luaran model ECHAM5 tersedia dalam dalam skala 3-jam-an, harian, bulanan, dan dapat diunduh dari laman https://esgf-node.llnl.gov/search/cmip5.

Setelah dilakukan pengecekan kelengkapannya, data diperiksa waktu jeda (timelag) antara data luaran model dengan data pengukuran. Jika antara kedua data tidak memiliki jeda waktu maka perhitungan selanjutnya dapat langsung dilakukan tanpa menggeser posisi tanggal hujan. Statistical downscaling dilakukan pada data model menggunakan metode rasio rata-rata dan menyusun model proyeksi untuk data hujan bulanan dan musiman menggunakan metode regresi sederhana dari pendekatan baik model linier maupun non linier. Pengujian akurasi model dilakukan dengan nilai koefisien korelasi Pearson (r), root mean square error (RMSE), dan nilai efisiensi model (Nash Sutcliffe efficiency).

\section{Pengujian waktu jeda}

\section{HASIL DAN PEMBAHASAN}

Korelasi silang (cross correlation) merupakan metode untuk memprediksi hubungan series data input (data $\mathrm{x}$ ) terhadap data output (data $\mathrm{y}$ ) pada suatu sistem. Metode korelasi silang ini banyak diaplikasikan untuk melihat hubungan dua kelompok data dalam analisis time series. Metode ini mensyaratkan pemakainya untuk memiliki sampel dua seri data dalam waktu yang sama dan diasumsikan stasioner delam means dan varians. Metode korelasi silang ini sering digunakan dalam menganalisis hubungan linier antara input dan output dalam kajian hidrologi maupun hidrologeologi seperti analisis waktu tunda antara curah hujan dan perubahan debit mata air, hubungan linier antara curah hujan satelit terhadap curah hujan terukur dan sebagainya (Ginting et al., 2019; RAZIN, 2021)

Cross correlation merupakan metode standar untuk mengestimasi sudut (degree) dari dua buah barisan/deret data (series) berkorelasi. Untuk dua buah deret x(i) dan y(i) dengan i $=0,1,2 \ldots \mathrm{N}-1$, nilai cross correlation $(\mathrm{r})$ setelah tunda d dinyatakan sebagai (Derrick and Thomas, 2004; Tahmasebi and Sahimi, 2013):

$$
r(d)=\frac{\sum_{i} x(i)-m(x)(y(i-d)-m y)}{\sqrt{\sum_{i}(x(i)-m x)^{2}} \sqrt{\sum_{i}(y(i-d)-m y)^{2}}}
$$

dengan mx dan my adalah nilai rerata masing masing barisan data. Deret x(i) adalah deret data hujan satelit dan deret y(i) adalah deret data hujan pengamatan. Hasil perhitungan nilai korelasi tertinggi terhadap waktu jeda disajikan pada tabel 1 . 
Tabel 1. Hasil perhitungan angka korelasi tertinggi terhadap waktu jeda antara data hujan ECHAM5 dan data hujan ARR di pulau Lombok

\begin{tabular}{lcc}
\hline Stasiun & \multicolumn{2}{c}{ Lag time (hari) } \\
\cline { 2 - 3 } & Lag time & Cross correlation \\
\hline Gunung sari & 0 & 0.107 \\
Kopang & 0 & 0.155 \\
Keruak & 0 & 0.150 \\
Jurang Sate & 0 & 0.234 \\
Sopak & 0 & 0.228 \\
\hline
\end{tabular}

Dari tabel 1 disimpulkan bahwa luaran model berkorelasi pada waktu yang sama dan tidak memiliki lag time (lag time $=0$ ). Sehingga data langsung dapat dianalisis tanpa harus menggeser tanggal hari hujan.

\section{Data Model ECHAM5}

Data yang digunakan dalam penelitian pemodelan ini adalah data hujan harian dan diolah menjadi data bulanan dan musiman. Gambar 1 berikut ini adalah data hujan harian hasil luaran model ECHAM5 yang disajikan bersamaan dengan data rekaman ARR untuk stasiun Gunung Sari tahun 2001-2005. ECHAM (European Centre Hamburg Model), adalah model sirkulasi global yang dirilis oleh Max Planck Institute for Meteorology (MPI) yang berpusat di Hamburg, Jerman. ECHAM dikembangkan dari versi awal (ca 1987) dari model prediksi cuaca numerik global yang dikembangkan di ECMWF, dan sejak itu terus dikembangkan di Institut Max Planck for Meteorologi. Versi ECHAM saat ini, ECHAM6, dikembangkan untuk mendukung kontribusi lembaga pada fase kelima dan keenam dari proyek model interkomparasi berpasangan (CMIP5 dan CMPI6)(Roeckner et al., 2003). Data luaran model ECHAM tersedia dan dapat diakses secara bebas.

Beberapa penelitian yang menggunakan data luaran ECHAM5 menyebutkan bahwa model ini memberikan hasil simulasi yang berlebihan dalam frekuensi namun cenderung kurang dalam intensitasnya (Nam and Quaas, 2012); namun model ini dapat menjelaskan perbedaan curah hujan pada daerah dengan topografi yang kompleks (Tselioudis et al., 2012). Metode ini juga terbukti unggul dan berkinerja tinggi setelah penskalaan lokal yang tepat khususnya untuk hujan bulanan pada wilayah Eropa, Amerika Utara dan Australia.(Eden and Widmann, 2014). Sehingga pada penelitian ini ingin dilakukan pengujian akan kemungkinan pemanfaatan model ECHAM5 ini untuk wilayah Lombok sebagai wilayah tropis yang belum terwakili dari studi sebelumnya.

Statistical downscaling digunakan untuk membuat data hujan hasil luaran model mendekati nilai hujan hasil pengukuran menggunakan metode perbandingan nilai rata-rata. Metode ini diujicobakan pada data hujan harian pada 5 stasiun yang dilibatkan dalam penelitian. Tahapan dilakukan dengan terlebih dulu memeriksa homogenitas data dengan menyeleksi dan mengeluarkan outlier dengan persamaan (Budiyono and Faisol, 2021):

$x>\mu \pm 3 \sigma$

Dimana $\mathrm{x}$ adalah data outlier $(\mathrm{mm}) ; \mu$ adalah nilai rerata hujan $(\mathrm{mm})$ dan $\sigma$ adalah nilai standar deviasi data hujan ( $\mathrm{mm})$. 
Penyesuaian data hujan harian luaran ECHAM5 dengan metode rasio nilai rata-rata. Secara umum, teknik koreksi data model global menggunakan metode rasio nilai rata-rata menggunakan persamaan berikut (Faqih, 2017):

$$
\begin{aligned}
& x_{c o r, i}=x_{m p, i}+\mu_{o b}-\mu_{m b} \\
& x_{c o r, i}=x_{m p, i} x \frac{\mu_{o b}}{\mu_{m b}}
\end{aligned}
$$

Dimana $: \mathrm{x}_{\mathrm{cor}, \mathrm{i}}=$ Nilai hasil koreksi periode ke $\mathrm{i} ; \mathrm{x}_{\mathrm{ob}, \mathrm{i}}=$ nilai observasi periode baseline; $\mathrm{x}_{\mathrm{mp}, \mathrm{i}}=$ nilai model pada periode proyeksi; $\mu_{\mathrm{ob}}=$ Rata-rata nilai observasi pada periode baseline; $\mu_{\mathrm{mb}}=$ rata-rata nilai model pada periode baseline. Pada umumnya koreksi data temperatur udara menggunakan persamaan (3) sedangkan persamaan (4) digunakan untuk mengkoreksi data hujan (Faqih, 2017; Suryadi et al., 2017).

Pada umumnya data hasil pemodelan hidrologi dievaluasi kesesuaiannya menggunakan nilai RMSE (root mean square error) dan NSE(Nash Sutcliffe Efficiency) dengan bentuk persamaan sebagai berikut: (Jain and Sudheer, 2008; Wang and Lu, 2018)

$$
R M S E=\sqrt{\frac{\sum_{i=1}^{N}\left(y_{m}-y_{o}\right)^{2}}{N}} \text { dan NSE }=1-\frac{\sum_{i=1}^{n}\left(y_{m}-y_{o}\right)^{2}}{\sum_{i=1}^{n}\left(y_{o}-\bar{y}_{o}\right)^{2}} \quad \text { (5) dan (6) }
$$

dimana $\mathrm{y}_{\mathrm{m}}, \mathrm{y}_{\mathrm{o}}$ dan $\bar{y}_{o}$ adalah nilai observasi, nilai model dan nilai rata-rata observasi.

Hasil yang diperoleh dalam perbaikan data hujan model menggunakan metode rasio nilai rata-rata secara umum belum menghasilkan perbaikan kualitas data yang memuaskan, meskipun terdapat peningkatan nilai efisiensi (NSE) disertai penurunan angka penyimpangan (RMSE). Baik akurasi data hasil koreksi (correction data) pada tahap kalibrasi serta tahap validasi (validation data), memberikan nilai kesesuaian yang masih rendah. Hal ini berarti pemodelan statistical downscaling hujan harian menggunakan metode rasio rata-rata, masih belum layak untuk digunakan. Hasil perbaikan data hujan dengan metode rasio nilai rata-rata disajikan pada gambar 1 . 


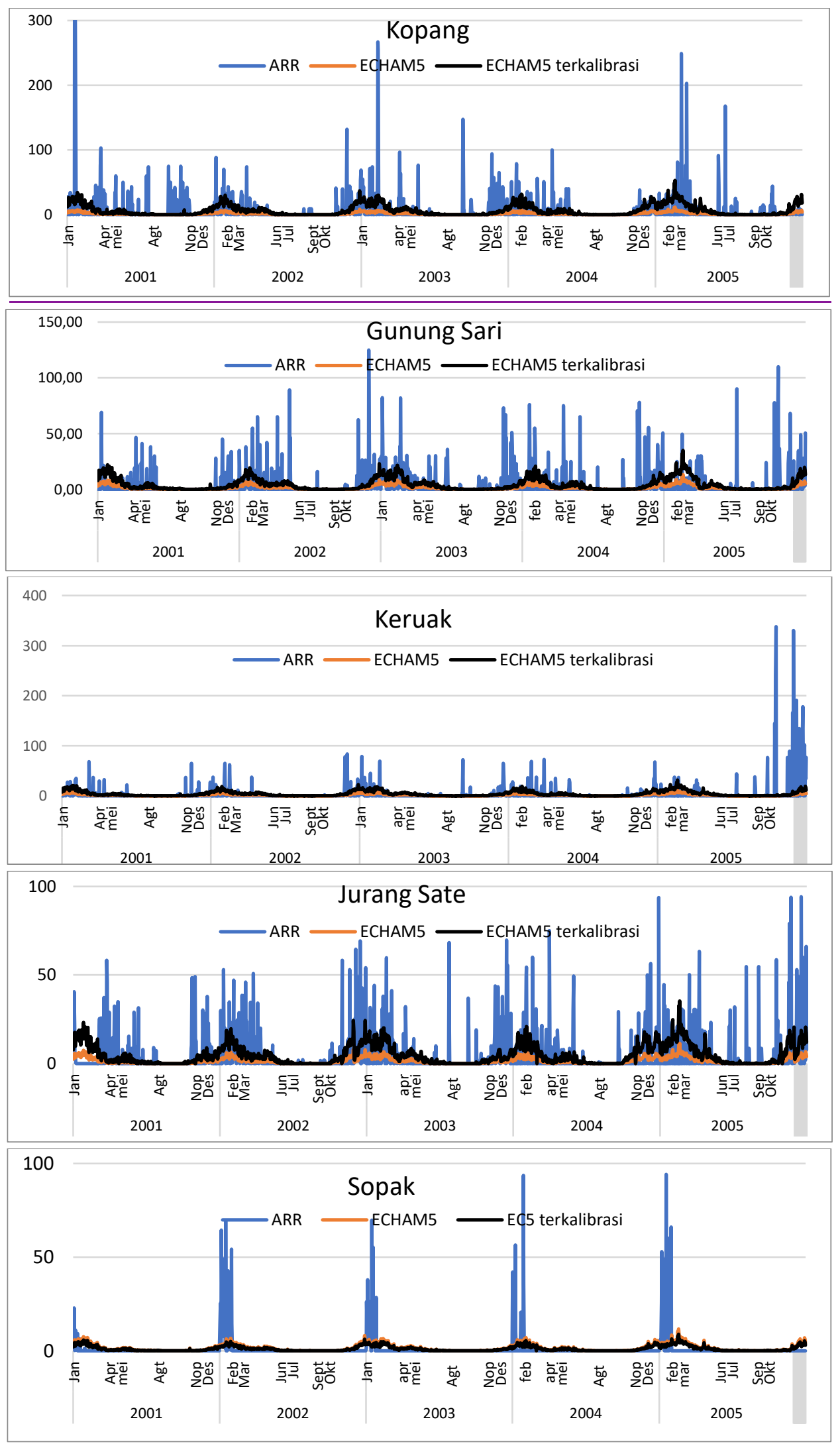

Gambar 1. Data hujan harian pada lima stasiun hujan di Pulau Lombok 
Gambar 1 memperlihatkan data hujan harian hasil pengukuran ARR (automatic Rainfall Recorder) Gunung Sari yang disajikan bersamaan dengan data hujan luaran model GCM ECHAM5 yang sudah diekstraksi dan dikalibrasi untuk 5 (lima) stasiun hujan yang ada di Pulau Lombok untuk periode tahun 2001-2005. Dalam grafik tersebut terlihat data hujan luaran ECHAM5 memiliki intensitas yang jauh lebih kecil dibandingkan hasil pengukuran dengan frekuensi hari hujan yang cenderung berlebihan, dimana hujan terjadi hampir setiap hari sepanjang tahun meskipun dengan intensitas yang rendah. Hal ini berkesesuaian dengan hasil penelitian yang disampaikan oleh Nam (2012) (Nam and Quaas, 2012).

Luaran model juga memberikan intensitas hujan yang terlalu rendah (underestimates) dan frekuensi hari hujan yang berlebihan pada stasiun lain yang dilibatkan dalam penelitian yaitu stasiun Kopang, Keruak, Jurang Sate dan Sopak. Kelima stasiun dipilih karena pertimbangan ketersebaran letak geografis, dimana kelima stasiun mewakili Kabupaten/Kota yang ada di Pulau Lombok, dan belum mempertimbangkan letak topografis. Namun kelima stasiun tersebut berada pada elevasi yang beragam dengan kondisi topografi yang bervariasi dari tanah datar hingga berbukit.

Tabel 2. Evaluasi pemodelan statistical downscaling hujan harian model ECHAM5

\begin{tabular}{llll}
\hline Stasiun & Evaluasi & ECHAM5 & ECHAM5 terkoreksi \\
\hline Gunung Sari & RMSE & 11.43 & 11.60 \\
& NSE & -0.02 & -0.05 \\
\hline \multirow{2}{*}{ Kopang } & RMSE & 23.10 & 22.73 \\
& NSE & -0.02 & 0.01 \\
\hline \multirow{2}{*}{ Keruak } & RMSE & 18.70 & 18.64 \\
& NSE & 0.00 & 0.01 \\
\hline Sopak & RMSE & 6.39 & 6.37 \\
& NSE & 0.05 & 0.05 \\
\hline Jurang Sate & RMSE & 11.51 & 11.36 \\
& NSE & -0.03 & 0.00 \\
\hline
\end{tabular}

Dengan cara yang sama langkah downscaling ini dilakukan pada data bulanan dan data musiman. Data yang dilibatkan dalam penyekalaan kecil untuk model bulanan sebanyak 204 bulan data (tahun 2000-2016) dan tahun 2017-2018 untuk validasi model, dan hasilnya disajikan pada gambar 2 .

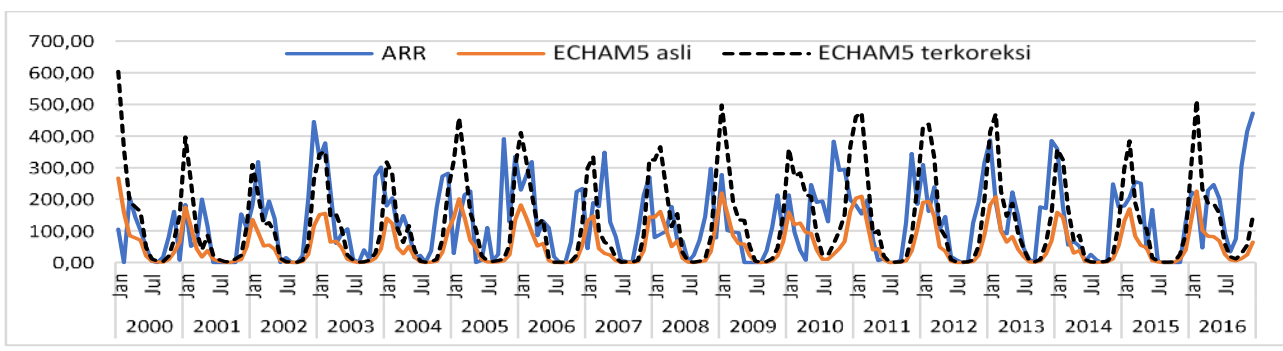

Gambar 2. Curah hujan bulanan ARR dan luaran model ECHAM5 stasiun Gunung Sari 
Pada pemodelan data bulanan diperoleh nilai evaluasi akurasi yang makin rendah jika dibandingkan dengan model data harian. Angka efisiensi yang dihasilkan model bulanan masih sangat rendah yaitu $-0,40$ untuk data setelah kalibrasi dan $-0,20$ untuk data sebelum kalibrasi. Namun demikian angka determinasi pada model bulanan ini lebih tinggi jika dibandingkan pada model data harian.

Rendahnya kinerja model statistical downscaling dengan metode rasio nilai rata-rata ini disebabkan karena makin tingginya penyimpangan nilai yang diakibatkan dari kumulatif nilai intensitas hujan bulanan antara kedua kelompok data. Tingginya frekuensi kumulatif hari hujan juga menyumbangkan tingkat ketidaksesuaian yang besar sehingga secara umum dapat dikatakan pemakaian data hujan bulanan model ECHAM5 yang teknik penyekalaan lokal menggunakan metode rasio nilai rata-rata belum menghasilkan angka pendekatan yang memadai di lokasi studi.

Perhitungan statistical downscaling selanjutnya dilakukan pada data musiman. Pada tahap ini data terlebih dahulu dipersiapkan dalam format musiman dengan cara dijumlahkan. Bulan April-September mewakili bulan kering (musim kemarau) dan Oktober-Maret untuk bulan basah (musim hujan). Data yang digunakan dalam tahap ini adalah data tahun 2000-2017, serta data tahun 2018 digunakan untuk validasi. Hasil evaluasi dan penyajian model musiman disajikan pada tabel 3 dan gambar 3 .

Tabel 3. Perhitungan koreksi data hujan musiman stasiun Gunung Sari

\begin{tabular}{|c|c|c|}
\hline & ECHAM5 & ECHAM5 terkoreksi \\
\hline \multicolumn{3}{|c|}{ Bulan kering (April-September) } \\
\hline korelasi & 0.75 & 0.75 \\
\hline RMSE & 348.09 & 170.20 \\
\hline NSE & -0.86 & 0.56 \\
\hline \multicolumn{3}{|c|}{ Bulan basah (Oktober-Maret) } \\
\hline korelasi & 0.13 & 0.13 \\
\hline RMSE & 656.49 & 622.40 \\
\hline NSE & -3.46 & -0.26 \\
\hline
\end{tabular}
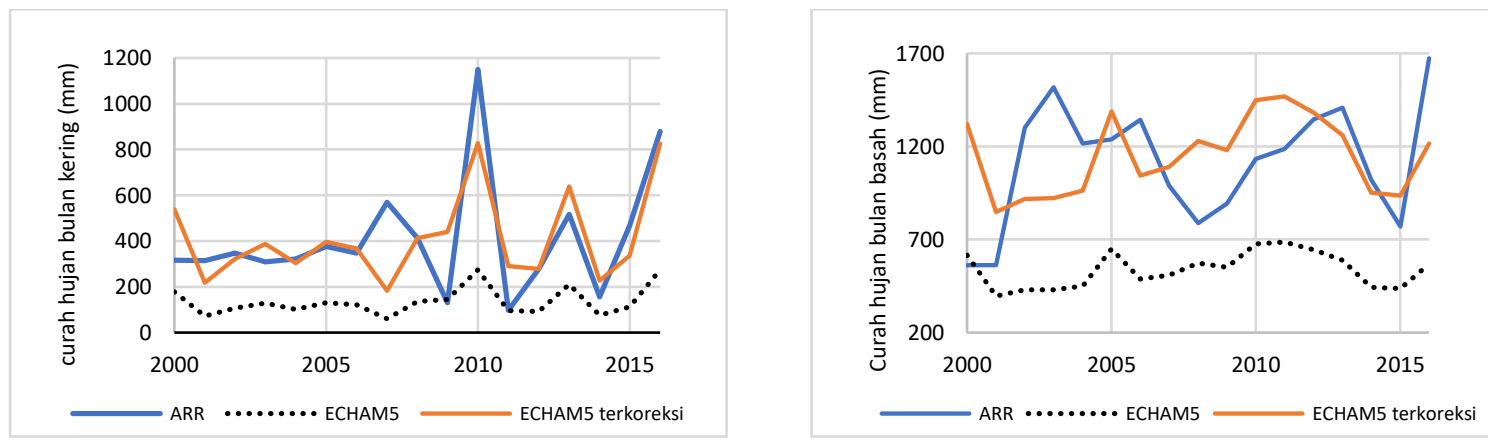

Gambar 3. Curah hujan musiman stasiun Gunung Sari tahun 2000-2016

\section{Model proyeksi curah hujan bulanan}

Pemodelan proyeksi curah hujan dilakukan untuk mendapatkan model untuk keperluan proyeksi curah hujan pada periode yang akan datang. Pemodelan dilakukan dengan pendekatan analisis regresi sederhana menggunakan data hujan bulanan antara tahun 2000-2016 dan 
musiman dan menggunakan data tahun 2017-2018 untuk data validasi. Pemilihan model terbaik dilakukan dengan estimasi model terlebih dahulu, baik dengan model linier maupun non linier. Model terbaik ditetapkan berdasarkan nilai korelasi tertinggi dan simpangan (eror) terkecil. Hasil pemodelan proyeksi curah hujan bulanan dan musiman tersebut kemudian dipilih yang terbaik dan selengkapnya disajikan pada tabel 4 dan validasinya disajikan dalam gambar 4.

Tabel 4. Model proyeksi data hujan harian bulanan dan musiman

\begin{tabular}{|c|c|c|c|c|}
\hline Stasiun & Model proyeksi & $\mathrm{R}$ & $\mathrm{R}^{2}$ & SEE \\
\hline Gunung Sari & $\mathrm{CH}=2.225+0,612 \mathrm{Ec} 5-0,104 \mathrm{Ec} 5^{2}$ & 0.178 & 0.032 & 11.138 \\
\hline Kopang & $\begin{array}{l}\mathrm{CH}=2.994+0,233 \mathrm{Ec} 5+0,033 \mathrm{Ec} 5^{2}- \\
0,001 \mathrm{Ec} 5^{3}\end{array}$ & 0.194 & 0.038 & 22.45 \\
\hline Keruak & $\begin{array}{l}\mathrm{CH}=1,441+0,571 \mathrm{Ec} 5+0,033 \mathrm{Ec} 5^{2}- \\
0,002 \mathrm{Ec}^{3}\end{array}$ & 0.159 & 0.025 & 18.517 \\
\hline Jurang Sate & $\begin{array}{l}\mathrm{CH}=1,493+1,137 \mathrm{Ec} 5-0,058 \mathrm{Ec} 5^{2}- \\
0,001 \mathrm{Ec}^{3}\end{array}$ & 0.247 & 0,061 & 11.018 \\
\hline Sopak & $\begin{array}{l}\mathrm{CH}=-0,341+1,364 \mathrm{Ec} 5+0,177 \mathrm{Ec} 5^{2} \\
-0,053 \mathrm{Ec5} 5^{3}\end{array}$ & 0.253 & 0.064 & 6.338 \\
\hline $\begin{array}{l}\text { Model hujan bulanan Gunung } \\
\text { Sari }\end{array}$ & $\begin{array}{l}\mathrm{CH}=44.26+3.506 \mathrm{Ec} 5-0.025 \mathrm{Ec}^{2}+ \\
5.241 .10^{-5} \mathrm{Ec}^{3}\end{array}$ & 0.538 & 0.289 & 96.823 \\
\hline $\begin{array}{l}\text { Model hujan musiman (bulan } \\
\text { kering) Gunung Sari }\end{array}$ & $\begin{array}{l}\mathrm{CH}=1112.944-14.129 \mathrm{Ec} 5+0.067 \\
\mathrm{Ec} 5^{2}-6.249 .10^{-5} \mathrm{Ec} 5^{3}\end{array}$ & 0.862 & 0.743 & 142.303 \\
\hline $\begin{array}{l}\text { Model hujan musiman (bulan } \\
\text { basah) Gunung Sari }\end{array}$ & $\mathrm{CH}=661.604 \mathrm{e}^{0.001 \mathrm{Ec} 5}$ & 0.466 & 0.217 & 0.551 \\
\hline
\end{tabular}

Keterangan: $\mathrm{CH}$ adalah curah hujan, dan Ec5 adalah data model ECHAM5
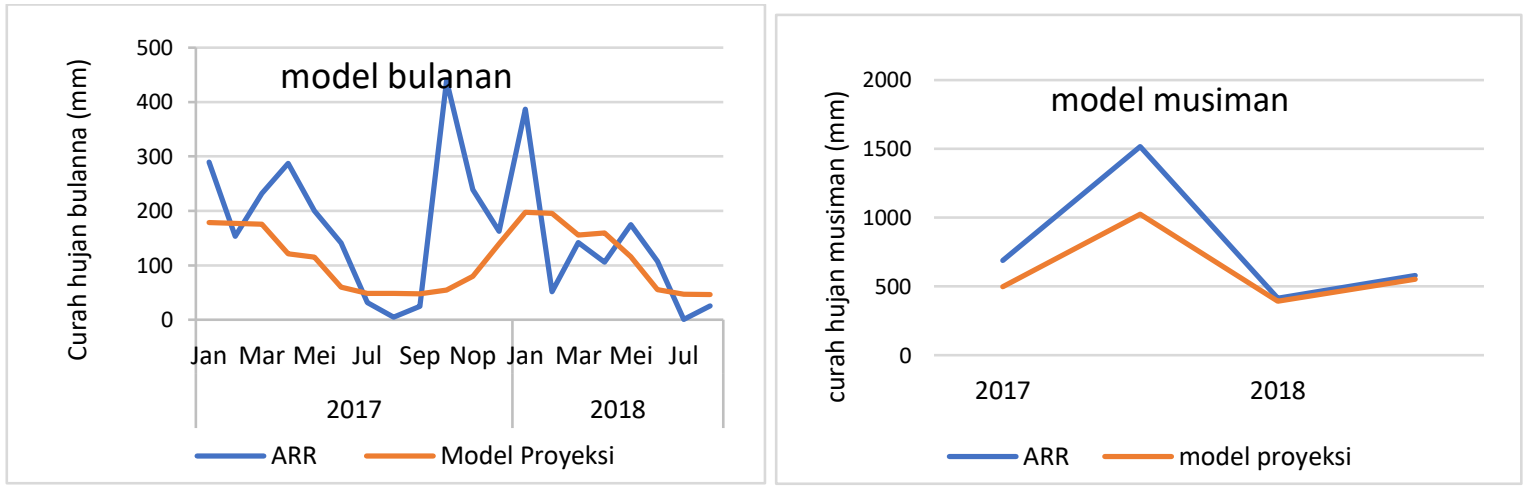

Gambar 4. Grafik validasi model proyeksi hujan bulanan dan musiman stasiun Gunung Sari

Berdasarkan rekapitulasi model proyeksi yang disajikan pada tabel 4, dapat dilihat bahwa model proyeksi curah hujan untuk periode musiman memiliki kinerja yang lebih jika dibandingkan model proyeksi untuk curah hujan bulanan maupun harian. Model curah hujan musiman terbaik dihasilkan untuk memproyeksi curah hujan pada musim kering (AprilOktober), dengan bentuk persamaan model kubik yang memiliki angka korelasi mencapai 0.862. Sedangkan model curah hujan bulanan terbaik juga diwakili oleh model kubik dengan angka korelasi sebesar 0.538. Model ini telah divalidasi menggunakan data hujan yang tidak disertakan dalam model dan mendapat angka korelasi yang memuaskan yaitu antara 0.386 untuk validasi model bulanan dan 0.99 untuk validasi model musiman. 


\section{KESIMPULAN}

Pemakaian metode rasio rata-rata dalam melakukan statistical downscaling data hujan harian dan bulanan luaran model ECHAM5 belum menghasilkan data hujan yang mendekati hasil pengukuran. Namun mampu menghasilkan ppendekkatan yang cukup baik pada data musiman. Model proyeksi data hujan menggunakan data ECHAM5 sebagai predictor dan hujan pengukuran sebagai prediktan memiliki kemampuan yang rendah untuk memproyeksikan data hujan harian, namun dapat digunakan untuk memproyeksi data hujan bulanan dan musiman dengan akurasi sedang hingga baik. Model terbaik untuk proyeksi curah hujan bulanan mengikuti persamaan $\mathrm{CH}=44.26+3.506 \mathrm{Ec} 5-0.025 \mathrm{Ec} 5^{2}+5.241 .10^{-5} \mathrm{Ec} 5^{3}$, sedangkan model hujan musiman terbaik diperoleh pada model proyeksi hujan bulan kering (April-Oktober), menggunakan persamaan $\mathrm{CH}=1112.944-14.129 \mathrm{Ec} 5+0.067 \mathrm{Ec} 5^{2}-6.249 .10^{-5} \mathrm{Ec}^{3}$.

\section{Ucapan Terimakasih}

Peneliti mengucapkan terima kasih kepada Universitas Mataram untuk dukungan dana dalam peneletian ini.

\section{DAFTAR PUSTAKA}

Abdulhalim, D.F., Tanudjaja, L., Sumarauw, J.S., 2018. Analisis Debit Banjir Dan Tinggi Muka Air Sungai Talawaan Di Titik 250 M Sebelah Hulu Bendung Talawaan. Jurnal Sipil Statik 6.

Aprilestari, N., Setiawan, A., Saidah, H., 2021. Analisis Keseimbangan Air Daerah Irigasi Gebong, Kecamatan Narmada Lombok Barat.

Araya-Osses, D., Casanueva, A., Román-Figueroa, C., Uribe, J.M., Paneque, M., 2020. Climate change projections of temperature and precipitation in Chile based on statistical downscaling. Climate Dynamics 54, 4309-4330.

Asyeifa, V.R., 2017. Pemodelan Statistical Downscaling Dengan Projection Pursuit Regression Untuk Meramalkan Curah Hujan Bulanan Di Sentra Produksi Padi Jawa Timur. ITS.

Azhar, K.J., Gunawan, T.A., 2021. Analisis Debit Andalan Untuk Probabilitas Terpenuhi Kebutuhan Air Irigasi Dalam Pengairan Lahan Pertanian Di Desa Paldas Kecamatan Rantau Bayur Kabupaten Banyuasin.

Budiyono, B., Faisol, A., 2021. Evaluasi Data Climate Hazards Group Infrared Precipitation With Station (Chirps) Dengan Data Pembanding Automatic Weather Stations (Aws) Dalam Mengestimasi Curah Hujan Harian Di Provinsi Papua BaratT. Jurnal Teknik Pertanian Lampung (Journal of Agricultural Engineering) 10, 64-72. https://doi.org/10.23960/jtep-1.v10i1.64-72

Bunganaen, W., Karbeka, N.S., Hangge, E.E., 2020. Analisis Ketersediaan Air Terhadap Pola Tanam dan Luas Areal Irigasi Daerah Irigasi Siafu. Jurnal Teknik Sipil 9, 15-26.

Chaniago, D., 2021. Kajian Kekeringan Meteorologis dengan Metode Standardized Precipitation Index (SPI) di Bagian Selatan Provinsi Daerah Istimewa Yogykarta (DIY).

Derrick, T.R., Thomas, J.M., 2004. Time series analysis: the cross-correlation function. 
Eden, J.M., Widmann, M., 2014. Downscaling of GCM-Simulated Precipitation Using Model Output Statistics. Journal of Climate 27, 312-324. https://doi.org/10.1175/JCLI-D-1300063.1

Faqih, A., 2017. A Statistical Bias Correction Tool for Generating Climate Change Scenarios in Indonesia based on CMIP5 Datasets. IOP Conf. Ser.: Earth Environ. Sci. 58, 012051. https://doi.org/10.1088/1755-1315/58/1/012051

Ginting, J.M., Sujono, J., Jayadi, R., 2019. Analisis Hubungan Data Hujan Satelit dengan Hujan Terukur ARR Kalibawang, in: Pros. Konf. Pascasarj. Tek. Sipil, No. November. pp. 89-102.

Hutama, W., Mursalin, M., Wulansari, S., 2021. Analisis Kebutuhan Dan Ketersediaan Air Di Desa Pulau Pandan Kecamatan Bukit Karman Kabupaten Kerinci.

Jain, S.K., Sudheer, K., 2008. Fitting of hydrologic models: a close look at the Nash-Sutcliffe index. Journal of hydrologic engineering 13, 981-986.

Maraun, D., Widmann, M., Gutiérrez, J.M., 2019. Statistical downscaling skill under present climate conditions: A synthesis of the VALUE perfect predictor experiment. International Journal of Climatology 39, 3692-3703.

Nam, C.C., Quaas, J., 2012. Evaluation of clouds and precipitation in the ECHAM5 general circulation model using CALIPSO and CloudSat satellite data. Journal of Climate 25, 4975-4992.

Negara, I.D.G.J., BUDIANTO, M.B., SUPRIYADI, A., SAIDAH, H., 2020. Analisis kebutuhan air tanaman dengan metode caoli pada tanaman tomat dengan irigasi tetes di lahan kering lombok utara. Ganec Swara 14, 419-425.

Nggarang, Y.E.P., Pattiraja, A.H., Henong, S.B., 2020. Analisa Perbandingan Penentuan Debit Rencana Menggunakan Metode Nakayasu dan Simulasi Aplikasi HEC-HMS di Das Lowo Rea. Eternitas: Jurnal Teknik Sipil 1, 23-33.

Novita, F., Harisuseno, D., Suhartanto, E., 2021. Studi Kekeringan Meteorologi dengan Menggunakan Metode Standardized Precipitation Index (SPI) dan China Z Index (CZI) di DAS Lekso Kabupaten Blitar. Jurnal Teknologi dan Rekayasa Sumber Daya Air 1, 648-660.

Osly, P.J., Dwiyandi, F., Ihsani, I., Ririhena, R.E., 2019. Analisis Kebutuhan Dan Ketersediaan Air Kabupaten Manokwari dengan Model Mock. Jurnal Infrastruktur 5, 59-67.

Pariartha, I.P.G.S., Arimbawa, I.K.D., Yekti, M.I., 2021. Analisis Debit Rencana Tukad Unda Bagian Hilir Menggunakan HEC-HMS. Jurnal Teknik Pengairan: Journal of Water Resources Engineering 12, 36-46. 